\title{
Auto-amputation of penis due to advanced carcinoma penis
}

\author{
Gaurav Garg, ${ }_{1}^{1}$ Nupur Bansal, ${ }^{2}$ Pragya Dixit, ${ }^{3}$ Ashish Sharma ${ }^{1}$
}

'Urology, King George's Medical University, Lucknow, UttarPradesh, India

${ }^{2}$ Radiotherapy, King George's Medical University, Lucknow, Uttar-Pradesh, India

${ }^{3}$ Pandit Bhagwat Dayal Sharma Post Graduate Institute of Medical Sciences, Rohtak, Haryana, India

\section{Correspondence to \\ Dr Gaurav Garg,} gougarg@gmail.com

Accepted 26 July 2018

\section{DESCRIPTION}

A 82-year-old Indian male patient was referred with complaints of the wound in right inguinal region for the last 15 days. He initially presented to a primary care centre with complaints of a progressive ulcer over penis for 12 months and swelling in right inguinal region for the last two months. He also revealed sloughing of penile tissue 1 month back. The discharged card mentioned that the patient received antibiotics and underwent incision/ drainage of the inguinal abscess under anaesthesia. $\mathrm{He}$ also had difficulty in micturition. The patient denied any history of sexually transmitted disease or local trauma. Clinical examination revealed almost complete loss of phallus. (figure 1). There was evidence of abscess in right inguinal region and hard matted nodes palpable in the left inguinal region. Metastatic workup revealed evidence of distant metastases. Biopsy from the base of residual penile stump revealed squamous cell carcinoma (figure 2). The patient underwent suprapubic cystostomy and was given palliative care for his symptoms but he succumbed in the next 15 days. In the present case, the patient neglected his initial symptoms and eventually developed penile auto-amputation, inguinal abscess and widespread metastasis. Advanced

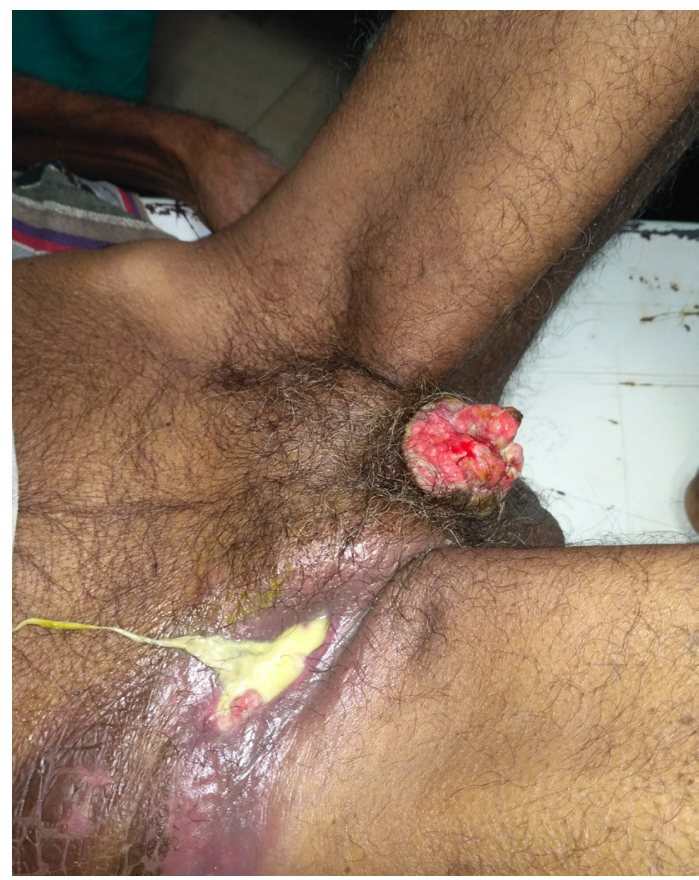

Figure 1 Clinical image depicting the almost complete loss of phallus with an abscess in the right inguinal region.

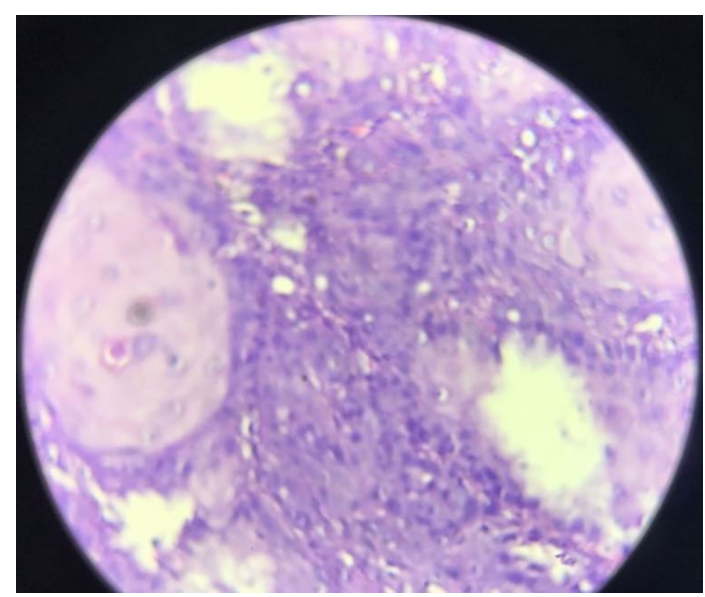

Figure 2 Histopathological image showing malignant epithelial cells disposed of in sheets and clusters. Individual atypical cells are pleomorphic with high nucleo cytoplasmic ratio, hyperchromatic nuclei, inconspicuous nucleoli and a moderate amount of cytoplasm. Occasional keratin pearls are also seen.

presentations of carcinoma penis occur due to ignorance and social stigma despite availability of sophisticated healthcare technology. ${ }^{1}$ Auto-amputation of the penis due to carcinoma penis is very rarely reported in the literature. ${ }^{2}$ Ghosh et al proposed that auto-amputation of the penis can occur either due to tumour emboli blocking end arteries or due to direct tumour invasion. ${ }^{3}$ Mumoli et al reported a similar case report of metastatic carcinoma penis presenting with auto-amputation in a 75 -year-old man. $^{4}$

\section{Learning points}

- Auto-amputation of the penis due to carcinoma penis is very rare.

- Auto-amputation of the penis can occur due to advanced and neglected carcinoma penis.

- Despite availability of advanced healthcare technology, advanced presentations of carcinoma penis occur due to ignorance and social stigma.

Contributors GG and NB: concept, design, supervision, processing, writing manuscript and critical analysis. AS and PD: supervision, processing, writing manuscript and critical analysis.

Funding The authors have not declared a specific grant for this research from any funding agency in the public, commercial or not-for-profit sectors.

Competing interests None declared.

Patient consent Next of kin consent obtained. 
Provenance and peer review Not commissioned; externally peer reviewed.

\section{REFERENCES}

1 Skeppner E, Andersson SO, Johansson JE, et al. Initial symptoms and delay in patients with penile carcinoma. Scand J Urol Nephrol 2012;46:319-25.
2 Pettaway CA, Lynch DF, Davis JW. et a/Tumors of the penis. In: Wein AJ, Kavoussi LR, Novick AC, Partin AW, Peters CA, . eds. Campbell-Walsh Urology. 9th edn. Philadelphia: Saunders-Elsevier, 2007:959-92.

3 Ghosh B, Manikandan R, Dorairajan LN, et al. Auto-amputation of penis due to carcinoma: still a threat in the era of modern medicine: report of two cases. Indian J Dermatol Venereol Leprol 2013;79:224-6.

4 Mumoli N, Giorgi-Pierfranceschi M, Porta C, et al. Penile self-amputation. Intern Emerg Med 2018.

Copyright 2018 BMJ Publishing Group. All rights reserved. For permission to reuse any of this content visit http://group.bmj.com/group/rights-licensing/permissions.

BMJ Case Report Fellows may re-use this article for personal use and teaching without any further permission.

Become a Fellow of BMJ Case Reports today and you can:

- Submit as many cases as you like

- Enjoy fast sympathetic peer review and rapid publication of accepted articles

- Access all the published articles

- Re-use any of the published material for personal use and teaching without further permission

For information on Institutional Fellowships contact consortiasales@bmjgroup.com

Visit casereports.bmj.com for more articles like this and to become a Fellow 